\title{
Exploiting eParticipation Using an Ontological Approach
}

\author{
Cleyton Slaviero ${ }^{1}$, Ana Cristina Bicharra Garcia ${ }^{1}$, and Cristiano $\mathrm{Maciel}^{2}$ \\ ${ }^{1}$ Instituto de Computação - Universidade Federal Fluminense - Niterói, RJ - Brazil \\ ${ }^{2}$ Instituto de Computação - Universidade Federal de Mato Grosso - Cuiabá, MT - Brazil \\ \{cslaviero, bicharra\}@ic.uff.br, cmaciel@ufmt.br
}

\begin{abstract}
When building an eParticipation environment, many questions arise. Who will the participants be? What are the outcomes? How will citizens interact? How will they be selected? All these questions will influence the specification of an eParticipation environment. In order to create an effective eParticipation environment, the designer pays attention to all these characteristics, which can be tricky, especially when selecting ICTs to support the eParticipation process. This paper suggests the use of an ontological approach when specifying these eParticipation environments, in order to reduce the designer's cognitive efforts when designing effective eParticipation environments.
\end{abstract}

Keywords: ontology design, specification phase, eParticipation environments.

\section{Introduction}

Recently, initiatives to bring togheter government and citizen raised new research questions regarding citizen participation in the matters of their being informed, consulted and making decisions using Information and Communication Technologies (ICTs) [1][2]. By using ICTs, e.g. chats, blogs, discussion fora voting tools and others, eParticipation environments are created by software engineers, reducing citizens efforts, as compared to traditional approaches for public participation [3]. In these environments, citizens are able to discuss their opinions, be informed of new topics and demands to be discussed and vote on such topics to reach a decision.

However, there are challenges in adding the "e" in participation. One of these challenges is the answer to the question "How do we select the appropriate tools in order that an eParticipation iniciative achieves its outcomes?". Selecting the right tools is important if we want to achieve the proper outcomes [4]. If the right tools are selected, they will certainly affect the course of the process positively and, as a consequence, its effectiveness [5].

Concerning tool selection, note that the effective access to software artifacts is only possible when the access to them is organized around the problem domain structure [6]. In this context, in order to acccess these software artifacts and to properly select them, it is necessary to fully understand the public participation context, dictated by participation methods, techniques or mechanisms [7][8][9]. These methods hold characteristics in common which are essential to create a public participation initiative. Each of these characteristcis will lead to necessary principles to build a 
participation environment. With these principles in hand, it is possible to start thinking of which tools may be employed to add the " $e$ " to participation.

One of our goals is to elucidate these questions, regarding which the characteristics of an eParticipation methods are, which are the eParticipation tools commonly applied to build an eParticipation process and how participation methods and ICT tools may be related to build an eParticipation environment. After clearing these questions, we add this knowledge to an ontology previsously created, called ePDO [3] by adding concepts and properties to it. By describing a use scenario we demonstrate how an ontological approach may help a designer to specify an eParticipation environment.

This paper is organized as follows. After this introduction, we briefly present participation and eParticipation concepts. After that, we describe participation methods and their characteristics, followed by the description of ICTs to enable participation. In the next section, we describe the additions made to ePDO in order to support the specification process. We also present a use scenario for this ontology. Finally, conclusions and future works are presented.

\section{Participation and eParticipation}

Participation is the act of taking part in something. In this context, citizens may have distinct levels of participation [10], from anecdotic participation, in which citizens are manipulated to believe that they have their voice heard, to real decision-making participation, when citizens share their opinions which are accounted in making decisions which affect them.

eParticipation describes citizens, by using information and communication technologies, being able to perform tasks common to participation, but in an online environment [11] [4]. It is correct to assume that these eParticipation tasks range from information, consultation and active participation [12]. The last category of participation is also split into involvement, collaboration and empowerment [13]. There are a number of distinct names for these participations contexts, but the important is that they all take into account the citizen as the center of the participation.

In this context, distinct eParticipation tools may be employed to create eParticipation environments [4][14] [11]. These may range from simpler ones, used in any context apart from eParticipation, to more specific tools to support this kind of participation.

To control the procedures and guarantee the correct outcomes, a participation or eParticipation may follow a participation method. There are a number of methods to promote participation [7]. However, authors state that only a few fit the active participation category [15][8].

When building eParticipation environments, it is important to consider the outcomes expected and the tools selected to create the eParticipation initiative, with the risk of building flawed citizen participation, which decreases citizens' confidence in these processes, making it harder for the citizen to participate. Indeed, the choice of the correct tools improve the correct progress of the eParticipation initiative, leading to these citizens' greater confidence [4]. In the next sections, we will provide a closer overview of these participation methods and ICTs, showing how to relate them when building eParticipation environments. 


\section{Characterizing Participation Methods}

Public participation encompasses consulting, involvement and information procedures to allow those affected by a decision to have an input. The way these inputs are gathered may be characterized by distinct participation methods [15].They may also be called public participation processes [8], mechanisms or techniques [7]. They will be called participation methods herein.

Each of these participation methods have a set of characteristics that define them, e.g. number of participants and participant selection [8]. In order to describe a common understanding of these, we performed a literature review searching for participation methods descriptions. The next paragraphs discuss the most relevant findings describing existing participation methods, along with their descriptions. From these descriptions, we present a set of common characteristics and describe the most relevant deliberative participation methods [15] using these characteristics.

Rowe and Frewer [15], in their paper about the evaluation of public participation methods, describe those who are closer to active citizen participation and more formalized in the literature. They are: Referendum, public hearings/inquiries, public opinion surveys, negotiated rule-making, consensus conference citizens' jury/panel, citizen/public advisory committee and focus groups.

The same authors also mentions guidelines for evaluating participation methods, which are very interesting to be observed if common characteristics of participation methods are to be extracted. These are divided into two dimensions: acceptance criteria, related to the public acceptance of the process, and process criteria, related to the effective construction and implementation of a procedure. Since the specification of eParticipation environments is being considered, we may pay closer attention to the second criteria. This dimension has as criteria: participants' access to appropriate resources to achieve their participation goals; scope, task and nature definitions for each activity during the participation; structured decision-making using appropriate mechanisms for decision-making process exhibition; and finally, cost/effectiveness.

Authors from [8] also present a discussion about design and evaluation of participation methods. In their work, the authors establish four elements that distinguish participation methods: selection of participants (which is also mentioned in [16]; number of participants; input type and number of meetings until a decision is made. Also, after analyzing distinct participation methods described in the literature, authors establish principles for designing and evaluating participation methods, divided into four elements: representation, regarding the way we represent the issues; procedures, related to the steps to execute one participation method, being these steps, e.g., duration, moderation or answers given by the public participating; information, which deals with the need to evaluate how information is selected, presented and interpreted; and results, regarding deliberation, e.g. how the outcomes were informed to the citizens, and which consensus was reached. Although this work seems similar to Rowe and Frewer's work, it provides guidelines to evaluate and to implement participation methods, whilst [15] provide a framework for evaluation.

There are also more detailed descriptions, although superficial ones, for running participation methods [9]. The author also highlights the need of correctly selecting a participation method to achieve an expected outcome. It considers four determinant 
characteristics for this choice: participation objectives; topic to be discussed; participants and their expertise; available time when searching for a solution; and budget available when running the method.

Rowe and Frewer [7] wrote about a topology of participation mechanisms. The authors describe the most relevant variables of these participation methods. They are: participants' selection method; information elicitation facilitation; information input form; information transfer form and information aggregation facilitation. These variables are described by the authors because they alter the effectiveness of the participation mechanisms.

After analyzing the abovementioned works, we have summarized our findings in a general set of characteristics used to describe a participation method, and also essential to be considered when building a public participation process. These are Participants selection, number of participants, form of participation, access to information, duration and presentation of results. Discussion over these characteristics are presented in details on [17].

We also applied these characteristics to the methods previously presented in [15], in order to show the coverage of these characteristics when used to describe participation methods. Table 1 shows the result of this description.

Table 1. Definition of Rowe and Frewer's participation methods[15] according to characteristics extracted

\begin{tabular}{|c|c|c|c|c|c|c|}
\hline & $\begin{array}{l}\text { Participants } \\
\text { Selection }\end{array}$ & $\begin{array}{l}\text { Number } \\
\text { of part. }\end{array}$ & $\begin{array}{l}\text { Form of } \\
\text { part. }\end{array}$ & Access to inf. & Duration & $\begin{array}{l}\text { Presentation } \\
\text { of results }\end{array}$ \\
\hline Referenda & Mandatory & Large & $\begin{array}{c}\text { One-question } \\
\text { poll }\end{array}$ & Government & Predefined & $\begin{array}{l}\text { Official } \\
\text { release }\end{array}$ \\
\hline \begin{tabular}{|l|} 
Public \\
hearings/ \\
inquires
\end{tabular} & Open & Large & $\begin{array}{c}\text { Open } \\
\text { discussion }\end{array}$ & Government & Open & $\begin{array}{c}\text { Press } \\
\text { release }\end{array}$ \\
\hline \begin{tabular}{|l|} 
Public \\
opinion \\
surveys
\end{tabular} & $\begin{array}{l}\text { Selective } \\
\text { (rep.) }\end{array}$ & $\begin{array}{c}\text { Medium } \\
\text { (between } \\
100 \text { and } \\
1000 \\
\text { citizens) }\end{array}$ & Survey & Government & Predefined & $\begin{array}{c}\text { Press } \\
\text { release }\end{array}$ \\
\hline \begin{tabular}{|l|} 
Negotiated \\
rule-making
\end{tabular} & Selective (i.) & Small & $\begin{array}{c}\text { Guided } \\
\text { discussion }\end{array}$ & Government & Open & $\begin{array}{l}\text { Official } \\
\text { release }\end{array}$ \\
\hline \begin{tabular}{|l|} 
Consensus \\
Conference
\end{tabular} & $\begin{array}{c}\text { Selective } \\
\text { (rep.) }\end{array}$ & Small & $\begin{array}{c}\text { Guided } \\
\text { discussion }\end{array}$ & Citizen & Predefined & $\begin{array}{c}\text { Press } \\
\text { release }\end{array}$ \\
\hline \begin{tabular}{|l} 
Citizens' \\
jury/ panel
\end{tabular} & $\begin{array}{l}\text { Selective } \\
\text { (rep.) }\end{array}$ & $\begin{array}{l}\text { Small }(12 / \\
20 \text { citizens })\end{array}$ & $\begin{array}{c}\text { Guided } \\
\text { discussion }\end{array}$ & $\begin{array}{c}\text { Citizen and } \\
\text { Government }\end{array}$ & Predefined & $\begin{array}{c}\text { Press } \\
\text { release }\end{array}$ \\
\hline \begin{tabular}{|l|} 
Citizen/ public \\
advisory \\
committee
\end{tabular} & $\begin{array}{c}\text { Selective } \\
\text { (rep.) }\end{array}$ & Small & $\begin{array}{c}\text { Guided } \\
\text { discussion }\end{array}$ & $\begin{array}{c}\text { Citizen and } \\
\text { Government }\end{array}$ & Open & $\begin{array}{l}\text { Press } \\
\text { release }\end{array}$ \\
\hline Focus groups & $\begin{array}{c}\text { Selective } \\
\text { (rep.) }\end{array}$ & $\begin{array}{l}\text { Small (5 to } \\
7 \text { citizens) }\end{array}$ & $\begin{array}{c}\text { Guided } \\
\text { discussion }\end{array}$ & $\begin{array}{c}\text { Citizen and } \\
\text { Government }\end{array}$ & Open & $\begin{array}{c}\text { Press } \\
\text { release }\end{array}$ \\
\hline
\end{tabular}

As Phang and Kankanhalli [4] mentions, each of the participation methods characteristics will have an influence in the building of an eParticipation environment. In our proposal, these characteristics will help us to establish principles for the specification of eParticipation environments.

When establishing principles for specifying these eParticipation environments, one must note that authors strongly recommend that these environments follow 
characteristics or principles of virtual communities [18]. On this matter, in [18] authors proposed three categories of principles for building eParticipation virtual communities: technical and content design; participants' social behavior; and interface design. Our principles relate to their technical and content ones. However, our work is based on participation methods and their characteristics and requirements. We describe these principles in detail in Table 2.

We can also associate these principles back to the participation methods. We notice that there are common principles to most of the participation methods. This occurs because such methods have similar deliberative characteristics associated to their execution, which demands that specific principles are followed. Table 3 shows these relationships, which will afterwards be used in our ontology for supporting the specification of eParticipation environments.

Table 2. Principles related to each characteristic identified

\begin{tabular}{|c|c|}
\hline Characteristic & Principles \\
\hline $\begin{array}{l}\text { Participants } \\
\text { selection }\end{array}$ & $\begin{array}{l}\text { P1: Environment should allow the access of participants through } \\
\text { registration, as in a virtual community. } \\
\text { P2: The environment should allow the selection of participants through a } \\
\text { selection tool. } \\
\text { P3: Environment should allow the sending of requests of participation by } \\
\text { the government, calling citizens to participate in activities }\end{array}$ \\
\hline $\begin{array}{l}\text { Number of } \\
\text { participants }\end{array}$ & $\begin{array}{l}\text { P4: Environment should allow structuring the environment for a small } \\
\text { number of participants } \\
\text { P5: Environment should allow structuring the environment for medium } \\
\text { number of participants } \\
\text { P6: Environment should allow structuring the environment for large } \\
\text { number of participants }\end{array}$ \\
\hline $\begin{array}{l}\text { Form of } \\
\text { participation }\end{array}$ & $\begin{array}{l}\text { P7: Environment should allow the definition of exhibition and propagation } \\
\text { of information by the participants. } \\
\text { P8: Environment should allow the definition of free discussion spaces. } \\
\text { P9: Environment should allow creating surveys with multiple questions. } \\
\text { P10: Environment should allow creating polls with a single question. } \\
\text { P11: Environment should allow creating a debate between citizens and } \\
\text { government exchanging opinions. } \\
\text { P12: Environment should allow the presence of moderators in discussions. } \\
\text { P13: Environment should allow the citizen to vote in one or more opinions. } \\
\text { P14: Environment should allow the moderator to regulate opinions, when } \\
\text { they are not in accordance with pre-established rules. }\end{array}$ \\
\hline $\begin{array}{ll}\text { Access } & \text { to } \\
\text { information }\end{array}$ & $\begin{array}{l}\text { P15: Environment should allow the insertion of information (text, image, } \\
\text { video, links, among others) by citizens } \\
\text { P16: Environment should allow the insertion of information by the } \\
\text { government (.e.g. open data). }\end{array}$ \\
\hline Duration & $\begin{array}{l}\text { P17: Environment should allow the administrator to put a timestamp on } \\
\text { participation processes. } \\
\text { P18: Environment should allow the environment to have a participation } \\
\text { process with no established ending date. }\end{array}$ \\
\hline $\begin{array}{l}\text { Presentation of } \\
\text { results }\end{array}$ & $\begin{array}{l}\text { P19: Environment should allow making information available about } \\
\text { deliberation made on it. } \\
\text { P20: Environment, via government, should allow to report the outcome of } \\
\text { the deliberation, in a general way, for participants }\end{array}$ \\
\hline
\end{tabular}


Table 3. Relationship between participation methods and principles

\begin{tabular}{|l|l|}
\hline Participation Method & Associated Principles \\
\hline Referenda & $\mathrm{P} 1, \mathrm{P} 6, \mathrm{P} 13, \mathrm{P} 16, \mathrm{P} 17, \mathrm{P} 20$ \\
\hline Public hearings/ inquiries & $\mathrm{P} 1, \mathrm{P} 6, \mathrm{P} 8, \mathrm{P} 13, \mathrm{P} 16, \mathrm{P} 18, \mathrm{P} 19$ \\
\hline Public opinion surveys & $\mathrm{P} 2, \mathrm{P} 3, \mathrm{P} 5, \mathrm{P} 9, \mathrm{P} 10, \mathrm{P} 16, \mathrm{P} 17$, \\
\hline Negotiated rule-making & $\mathrm{P} 2, \mathrm{P} 3, \mathrm{P} 4, \mathrm{P} 11, \mathrm{P} 16, \mathrm{P} 18, \mathrm{P} 20$ \\
\hline Consensus Conference & $\mathrm{P} 2, \mathrm{P} 3, \mathrm{P} 4, \mathrm{P} 7, \mathrm{P} 11, \mathrm{P} 12, \mathrm{P} 14, \mathrm{P} 16, \mathrm{P} 17, \mathrm{P} 19$ \\
\hline Citizens' jury/ panel & $\mathrm{P} 2, \mathrm{P} 3, \mathrm{P} 4, \mathrm{P} 7, \mathrm{P} 11, \mathrm{P} 12, \mathrm{P} 14, \mathrm{P} 15, \mathrm{P} 16, \mathrm{P} 17, \mathrm{P} 19$ \\
\hline Citizen/public advisory committee & $\mathrm{P} 2, \mathrm{P} 3, \mathrm{P} 4, \mathrm{P} 7, \mathrm{P} 8, \mathrm{P} 15, \mathrm{P} 16, \mathrm{P} 18, \mathrm{P} 19$ \\
\hline Focus groups & $\mathrm{P} 2, \mathrm{P} 3, \mathrm{P} 4, \mathrm{P} 11, \mathrm{P} 12, \mathrm{P} 14, \mathrm{P} 15, \mathrm{P} 16, \mathrm{P} 18, \mathrm{P} 19$ \\
\hline
\end{tabular}

\section{$4 \quad$ ICTs to Enable eParticipation}

The use of ICTs to promote citizens' participation is evidenced in works [4], reports and analysis of ways to promote citizens' participation [19] [11]. In order to add the "e" in participation, it is important to use tools which support all the stages of online participation processes.

In the literature, there are many definitions for these ICTs [20] [14][4][11]. This plurality of definitions may be upsetting when selecting ICTs to build an eParticipation environment. Distinct definitions often mix technologies and tools, making it harder to understand which ones are tools and which ones are technologies and the possible reuse of these tools in other eParticipation initiatives.

Aiming at classifying tools for eParticipation, we consider, from the related works, tools in which the end user is the citizen or the government, i.e., there are interaction among the users using these tools. The tools analysed were the ones described by Thorleifsdottir \& Wimmer [11], which are the most complete description of these tools when compared to other analyses.

By analyzing these tools, we also notice that some functionalities are transverse to many tools, e.g. the need for a profile to register the citizen. We call these functionalities ICT components. The following are the components identified, and the tools that implement these functionalities:

- Chat: provides a space for free discussion among participants, with no focus on a single subject. Related ICT: eParticipation Chat Rooms

- Profile: allow the user to register for an environment, virtually becoming a part of it. This component can be considered fundamental when you want to start a process of participation, as participants must identify themselves. Related ICTs: all those described.

- Forum: Unlike Chat, a forum is structured by topics, to facilitate discussion. Discussion is free, but moderation may be needed. ICT identified: eParticipation Discussion Forum / Board

- Debate: enables debating about a given topic. In this debate, citizens share their opinions and vote against, neutrally or favorably to a topic. An interaction 
language may be used to structure discussion, such as DemIL [21]. ICT identified: ePanel, eDeliberative Polling.

- Information Provision: allows one to make information available for citizens through a number of sources: audio, video, wikis, blogs, podcasts, videocasts, links or documents uploaded. ICTs identified: Podcasts, Wiki, Blog, and FAQ.

- Petition: Employ when creating petitions. These petitions can be created when citizens want to gather signatures for a specific topic to be discussed by the government. ICT identified: ePetitioning.

- Meeting: ICT for creating meeting spaces between citizens and government. Meeting can take place in real time or not. Government and citizens are may exchange opinions. ICT identified: Webcast.

- Survey: provides a way for creating a set of questions to be answered by citizens. ICT Identified: eConsultation, eDeliberative Polling.

- Poll: Component for creating a single poll with one question to be answered by citizens. In this component, citizens do not need to be identified; however, it is possible for them to do so. ICT identified: eConsultation, eDeliberative Polling.

- Voting: ICT Component for creating an official voting. Like a poll, a question may be answered by the citizens. However, the citizen must be identified as a registered voter, although this registration would not be necessarily related to his/her choice. When implementing this component, additional security questions must be considered. ICT identified: eVoting.

- Alert: ICT component that account for sending citizens alerts about topics of their interest or to call them to participate in a given participation process. ICT identified: Alert services, online newsletters, Listserv.

It is important to notice that although the Demo-net report presents these tools, they are not final, and many other tools may be employed. However, they represent a great number of ways for implementing participation processes. Moreover, the ICT components identified are not final. They will need to be adapted to distinct contexts of participation. The goal when summarizing these ICT components is to extract their common functionalities, in order to allow the reuse of these functionalities in other eParticipation initiatives, and thus help the selection of ICTs to implement when specifying an eParticipation environment.

\section{Connecting Principles with ICT Components}

In order to have an eParticipation environment, the principles described in Table 2 need to be implemented by the ICTs, which are built by ICT components, primarily. The principles are related with these ICT in Table 4.

When associating principles with ICT components identified, some interesting issues arise. Petition component did not have any principle associated to it. One may argue that this is because this is not a formalized participation method, but a way for citizens to start a participation initiative. Regarding the principles, P15 was mentioned both as being implemented by Debate or by a Meeting. The selection of the component in this case depends on how the government will interact with citizens. 
Another intriguing question is that not all principles have a relation with a component. This means that these principles were not thought of when using these tools, but may also mean that the ICTs implicitly implement these principles. In order to organize uncovered principles, five additional components are suggested in order to complement these missing principles.

- Selection: Component for selecting participants in a given participation process. Principle identified: P2.

- Environment Organization: Component for organizing the environment according to the number of citizens. This organization may be conducted by adapting the interfaces for multiple users, e.g. when these are in a forum. Principles identified: P4, P5, P6.

- Duration: Component to organize the duration of the processes. Principles identified: P17, P18.

- Moderation: Component that deals with moderation, e.g. allow selecting a moderator, and giving this citizen power to moderate discussions. Principles identified: P12,P14.

- Result: Component that organizes the results and output them adequately, according to the specification of the process. Principles identified: P19, P20.

Table 4. Relationship between ICT components and Principles

\begin{tabular}{|l|l|}
\hline Component & Principles implemented \\
\hline Chat & P7 \\
\hline Profile & P1 \\
\hline Forum & P8 \\
\hline Debate & P11 \\
\hline Information Provision & P15, P16 \\
\hline Petition & No principle identified \\
\hline Meeting & P11 \\
\hline Survey & P9 \\
\hline Poll & P10 \\
\hline Voting & P13 \\
\hline Alert & P3 \\
\hline
\end{tabular}

\section{Description of the Extension of the Ontology}

When building an eParticipation environment, many questions arise. Who will the participants be? What are the outcomes? How will citizens interact? How will they be selected? All these questions will influence the specification of an eParticipation environment.

Ontologies are adequate to answer these questions. Given these and many other advantages of ontologies [22], we propose the use of an ontology to help the specification of these systems. When using concepts to describe the characteristics of participation methods and ICT along with ICT components and principles and properties among all these concepts, we can turn the ontology into a powerful 
mechanism to support the designer when specifying an eParticipation environment. By using ontology, the decision when choosing ICTs to build the environment is now shared between ontology and designer of the environment, with the ontology being a knowledge base that can be expanded by the very designer, if there is the need for doing so.

An initial version of the ontology and a model for applying this ontology in the specification of an eParticipation environment has been mentioned before [3]. This ontology is called ePDO (eParticipation Domain Ontology). In this work, our goal was to expand it by defining the relationship among participation methods and ICTs in order to support the designer in the specification of these environments.

The abovementioned sections elucidate the relationships among participation methods and ICTs that a designer would search when building an eParticipation initiative. This information will allow us to evolve the ontology previously described in [3]. A new version of ePDO is presented in Figure 1 and explored in details on the following subsections. We omitted some concepts to make it clearer for the reader to understand the new additions to ePDO.

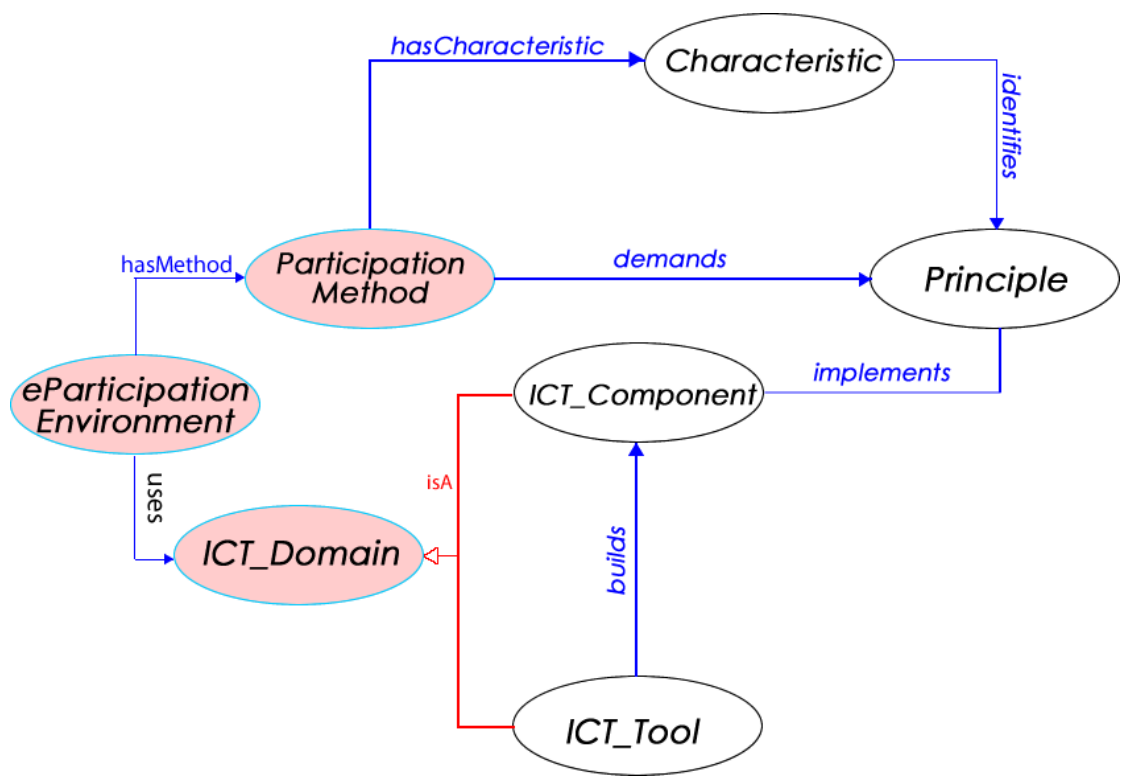

Fig. 1. A portion of ePDO[3], painted, and new terms, unpainted

\subsection{New Terms and Properties of the Ontology}

New concepts and properties must be added to the ontology to allow a designer to use it as a support for specifying an eParticipation environment. These concepts are:

- Characteristics: Class containing the characteristics described as relevant to define participation methods, as mentioned in Section 2. 
- Principles: This class contains as subclasses each principle captured from the characteristics of participation methods.

- ICT_Domain: This class contains two subclasses: ICT_Component and ICT_Tool. The former contains as subclasses the components identified in the ICTs, while the latter contains the ICT tools described by [11].

The evolution of the ontology is not complete if concepts are added. It is necessary to add the knowledge to relate these concepts so that the ontology will contain the knowledge to help a designer in the specification of the eParticipation environment.

These new properties (along with their inverse properties) are the following:

- builds/isBuiltBy: Relationship between an ICT Tool and the ICT components necessary to build one ICT Tool, as described in Section 5.

- Demand/isDemandedBy: Relationship between participation methods and principles, as in Table 3.

- Implements/isImplementedBy: Relationship between ICT components and principles, as in Section 6.

- hasCharacteristic/isCharacterizedBy: Relationship between participation methods and characteristics, as in Section 4.1.

- identify/isIdentifiedBy: Relationship between characteristics and principles.

\subsection{A Method for Using the Ontology}

Suppose that a designer need to build an eParticipation environment (e.g. a referendum) as a demand given by the government. In this referendum, people of a country will one question to answer. Citizens will be able to discuss these questions and the alternatives to the latter.

Guided by the ontology, the designer starts by describing the characteristics of the referendum. The ontology has the knowledge to associate characteristics of a referendum to principles (through the identifies property). Each principle is related to ICTs components (through the implements property). These ICT components, when aggregated, will build one or more ICTs (shown by the property builds). At this time, the designer will have the information of which ICTs he will need to design and implement to build this eParticipation environment. Figure 2 illustrates this process.

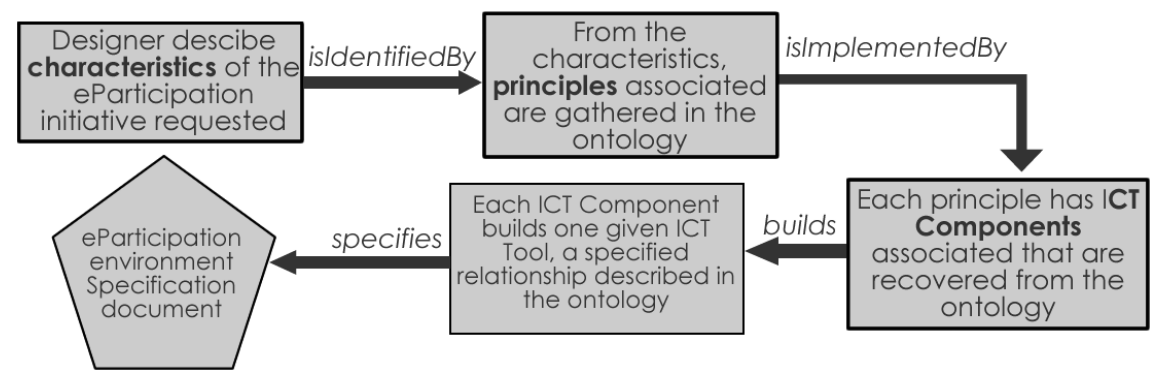

Fig. 2. Knowledge discovery process on the ontology 


\section{Conclusions and Future Works}

This paper proposes the use of an ontological approach to support the specification of eParticipation environments. To perform such a task, we analyzed the relationship between participation methods and ICTs, defining principles for building eParticipation processes and ICT components to use when building such processes In this paper, the knowledge acquisition was in evidence, rather than an implementation of the ontology.

One thing that should be mentioned is that, when using ontologies to specify eParticipation environments, the designer, from the very beginning, may find dependencies and necessary components to build these environments, which makes it important to implement an environment aligned with the citizens' needs and the outcomes expected, essential to perform an efficient eParticipation process [5].

As future works, we intend to seek to reuse the ontology in other parts of the software lifecycle of the building of eParticipation environments [23] aiming at automating the process of building these environments [3] and using components as building blocks to implement them [24]. Testing with designers with expertise in electronic government using the ontology to specify eParticipation environments will be performed, in order to validate and to improve this solution.

Acknowledgment. Authors would like to thank FAPEMAT, UFMT/Uniselva and CAPES for partial funding to support this research.

\section{References}

1. Sæbø, Ø., Rose, J., Flak, L.S.: The shape of eParticipation: Characterizing an emerging research area. Government Information Quarterly 25, 400-428 (2008)

2. Macintosh, A., Coleman, S., Schneeberger, A.: eParticipation: The Research Gaps. In: Macintosh, A., Tambouris, E. (eds.) ePart 2009. LNCS, vol. 5694, pp. 1-11. Springer, Heidelberg (2009)

3. Slaviero, C., Garcia, A.C.B., Maciel, C.: Towards an Ontology to Support the Deployment of eParticipation Environments. In: Andersen, K.N., Francesconi, E., Grönlund, Å., van Engers, T.M. (eds.) EGOVIS 2011. LNCS, vol. 6866, pp. 146-160. Springer, Heidelberg (2011)

4. Phang, C.W., Kankanhalli, A.: A framework of ICT exploitation for e-participation initiatives. Communications of the ACM 51, 128 (2008)

5. Velikanov, C.: Requirements and tools for an efficient eParticipation. In: Proceedings of the 11th Annual International Digital Government Research Conference on Public Administration Online: Challenges and Opportunities, pp. 32-40. Digital Government Society of North America (2010)

6. Clayton, R., Rugaber, S., Wills, L.: Dowsing: a tool framework for domain-oriented browsing of software artifacts. In: Proceedings 13th IEEE International Conference on Automated Software Engineering (Cat. No.98EX239), pp. 204-207. IEEE Comput. Soc. (1998)

7. Rowe, G., Frewer, L.J.: A Typology of Public Engagement Mechanisms. Science, Technology \& Human Values 30, 251-290 (2005) 
8. Abelson, J., Forest, P.-G., Eyles, J., Smith, P., Martin, E., Gauvin, F.-P.: Deliberations about deliberative methods: issues in the design and evaluation of public participation processes. Social Science \& Medicine 57(2003), 239-251 (1982)

9. Slocum, N.: Participatory Methods Toolkit - A practitioner's manual. ViWTA and King Baudoin Foundation (2003)

10. Arnstein, S.R.: A Ladder of Citizen Participation. Journal of the American Planning Association 35, 216-224 (1969)

11. Thorleifsdottir, A., Wimmer, M.A.: DEMO-net: Deliverable 5.1 Report on current ICTs to enable Participation (2006)

12. OECD: Citizens as Partners - OECD Handbook on Information, Consultation and Public Participation in Policy-Making. OECD Publishing (2001)

13. IAP2: IAP2 Spectrum of Public Participation (2007)

14. Kumar, N., Vragov, R.: Active citizen participation using ICT tools. Communications of the ACM 52, 118 (2009)

15. Rowe, G., Frewer, L.J.: Public Participation Methods: A Framework for Evaluation. Science, Technology \& Human Values 25, 3-29 (2000)

16. Mulgan, G., Blears, H.: People \& Participation (2005)

17. Slaviero, C., Garcia, A.C.B., Maciel, C.: Métodos de participação e Tecnologias de Informação e Comunicação: transformando participação em eParticipação. In: IV Workshop de Computação Aplicada em Governo Eletrônico, pp. 17-24 (2012)

18. Maciel, C., Roque, L., Garcia, A.C.B.: E-Democracy: Concepts, Experiences and Challenges. In: Herrmann, P. (ed.) Democracy in Theory and Action, pp. 51-92. Nova Science Publishers, Inc., New York (2011)

19. IAP2: Public Participaton Toolbox (2000)

20. Tambouris, E., Liotas, N., Tarabanis, K.: A Framework for Assessing eParticipation Projects and Tools. In: Proceedings of the 40th Hawaii International Conference on System Sciences, Hawaii, pp. 1-10. IEEE (2007)

21. Maciel, C., Garcia, A.C.B.: DemIL: an online interaction language between citizen and government. In: Proceedings of the 15th International Conference on World Wide Web, pp. 849-850. ACM, Edinburgh (2006)

22. Noy, N.F., McGuinness, D.L.: Ontology development 101: A guide to creating your first ontology (2001), http: / / citeseerx.ist.psu.edu/viewdoc/ download?doi=10.1.1.136.5085\&amp; rep=rep1\&amp; type=pdf

23. Happel, H., Seedorf, S.: Applications of ontologies in software engineering. In: Proc. of Workshop on Sematic Web Enabled Software Engineering (SWESE) on the ISWC, Citeseer, pp. 5-9 (2006)

24. Maciel, C., Slaviero, C., Souza, P. C., Campos, M. A. D., Santana, E. C.: Platform design details to support eparticipation environments deployment. In: Third IFIP WG 8.5 International Conference on eParticipation (ePart 2011), Delft. Electronic Government and Electronic Participation, vol. 37, pp. 382-391. Trauner Verlag, Austria (2011) 